\title{
Las casas de la memoria
}

\author{
Rubén Chababo
}

El ensayo puede ser leído como una reflexión poética acerca del modo en que algunos poetas han abordado el tema de la casa natal como espacio fuertemente referencial. Desde la nostálgica evocación con que Joseph Brodsky recuerda su hogar desde el exilio, pasando por algunos registros de la poesía hebraico-española hasta llegar a la desgarrada enunciación de los lugares propios, abandonados por razón del destierro, en los versos de José Kozer, el ensayo apuesta a señalar el maravilloso poder de la escritura para recuperar aunque sólo sea simbólicamente, aquello que fue arrebatado de manera implacable por el paso del tiempo.

The essay can be read as a poetical reflexion about the way in which some poets have tackled the subject about the house where they were born, as a space of deep significance. From the nostalgic evocation with which Joseph Brodsky remembers his home from the exile, passing by some records of Hebraic-Spanish poetry until reaching the heart breaking statements about the own places abandoned because of the exile in José Kozer's verses, the essay is committed to point to the marvellous power of writing to recover, even if only symbolically, all that was snatched in an implacable way by the passing of time. 



\author{
Rubén A. Chababo \\ Universidad Nacional de Rosario, Museo de la Memoria, \\ Rosario, República Argentina
}

\title{
Las casas de la memoria
}

Sutil pretérito el de las cosas muertas. Siguen vivas, continuando, en la memoria de uno y sin embargo ya no son. Dejaron de ser, se abandonaron, y son sólo esa mancha leve y descolorida que deja en la memoria la exudación producida por los recuerdos y los sentimientos. Sutiles pretéritos, que ya no son y siguen siendo.

Sergio Chejfec, Lenta biografía

La escena transcurre en 1985, en una habitación de una casa en Canadá. Es invierno y el poeta ruso Joseph Brodsky escribe una extensa memoria acerca de sus padres, de quienes lo separan el océano y el exilio. El texto lleva por nombre "En

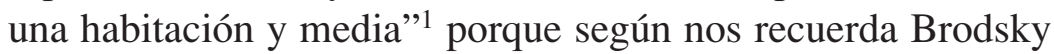

${ }^{1}$ Brodsky 1995. No es mi intención hacer aquí una lectura rigurosa de la obra de Joseph Brodsky. La elección de este texto responde a la posibilidad que brinda de ejemplificar algunas ideas y a la indiscutible riqueza de las imágenes y sensaciones que despliega. Se trata de un recorte de un fragmento perteneciente a un poderoso universo textual, nunca una apreciación que deba ser entendida como lectura 
esa medida era la que el Estado soviético había determinado como suficiente para que su familia viviera. Desde Canadá entonces, desde la calidez y la amplitud de su cuarto caldeado de Occidente, el poeta recrea a través de la escritura la estrechez a la que el autoritarismo recluyó a los suyos. Y con ella recuerda la juventud de sus progenitores, la luz de su ciudad natal en los inviernos, los aromas de las comidas, el rostro de su padre, la indescriptible paciencia de su madre para soportar los atropellos a los que en vida los sometió el estalinismo.

Más allá de las infinitas potencialidades que este texto posee como herramienta para comprender el funcionamiento de las sociedades autoritarias, hay un dato nada menor que Brodsky hace saber al lector futuro del texto, y es que éste ha sido escrito en inglés.

Escribo esto en inglés porque quiero concederles un margen de libertad, un margen cuya amplitud depende del número de los que están dispuestos a leerlo. Quiero que María Volpert y Alexander Brodsky cobren realidad bajo un código de convivencia extranjero y quiero que los verbos de movimiento del inglés describan sus movimientos. Esto no servirá para resucitarlos, pero, por lo menos, otras gramáticas pueden demostrar ser mejores rutas de escape de las chimeneas del crematorio estatal que el ruso. Escribir sobre ellos en ruso sería sólo ampliar su cautividad, su reducción a la insignificancia [....]. Sé que no habría que comparar el Estado con el idioma, pero fue en ruso que dos viejos, que se arrastraron durante doce años por las numerosas cancillerías y ministerios del Estado con la esperanza de conseguir un visado para ir al extranjero a ver a su único hijo antes de que les llegara la muerte, oyeron la respuesta que les reveló que el Estado consideraba aquella visita fuera de lugar. ${ }^{2}$

totalizadora de una poética. No cabe duda de que hay otros textos de Brodsky —en especial poemas - en los que podríamos visualizar de modo más exhaustivo las complejas relaciones posibles de establecer entre memoria, exilio y escritura.

${ }^{2}$ Brodsky 1995. 
Allí donde las leyes biológicas y jurídicas ya no pueden hacer nada, el idioma oficia como pasaporte imaginario para alcanzar la libertad. Los padres ya muertos de uno de los mayores poetas de la lengua rusa contemporánea, resucitan en la página gracias a la intervención de la lengua del exilio. Vuelven a andar en otra lengua, a ser aquellos sujetos libres que el idioma ruso les impidió ser. El inglés de Brodsky diseña así un territorio de libertad, una patria provisoria, un asilo, donde poder acunar el recuerdo de los suyos.

Esta escena de rescate a través de la lengua puede ser vista como una ingeniosa forma de salvar aquello de que el poder y el exilio se han apropiado de manera inexorable. Una treta, una treta diseñada por el débil, para hacer frente a la ominosa maquinaria del Estado.

Para aquellos que han sido arrojados a la intemperie del exilio, para los obligados a habitar un más allá de los límites de lo propio, la lengua es, no cabe duda, balsa de salvación o conjuro, acaso el único refugio donde proteger el alma y, como en el caso de Brodsky, salvar a los que se ama.

En ese canje de una lengua por otra, del inglés por el ruso, hay, no cabe duda, una denuncia en ciernes: la lengua que alguna vez permitió espumar la prosa de Dostoievski y de Tolstoi, la que impulsó la pluma de Ana Ajmátova o Boris Pasternak, está contaminada por el uso burocrático de la maquinaria estalinista. Sin decirlo explícitamente, Brodsky insinúa que en un futuro cercano, cuando la Unión Soviética no sea más que una referencia en los libros de historia, acaso será necesaria una limpieza de la lengua, una purificación de un idioma que, como el alemán en su momento, debió sacarse de encima la vergüenza de haber sido la lengua de los verdugos.

Pero mientras las puertas físicas de regreso al hogar permanezcan cerradas, la única forma de traspasar el umbral que la ley impone para el exiliado es escribir, para de ese modo traer a los suyos a su cercanía. 
Asegura el poeta:

¿Cómo es posible que yo me vea a mí en ese escenario? Y sin embargo es así: me veo tan claramente como los veo a ellos. Vuelvo a decir que no es nostalgia de juventud, de mi país, no, sino que es probable que, puesto que ahora ellos han muerto, vea yo su vida tal como era entonces y entonces en su vida estaba yo. Esto es lo que ellos recordarían de mí, a menos que posean ahora el don de la omnisciencia y me estén observando en este momento, sentado en la cocina del apartamento que he alquilado a mi escuela, escribiendo todo esto en una lengua que ellos no entenderían. Ésta es su única posibilidad de verme a mí y de ver América. Y para mí es la única forma de verlos a ellos y de ver nuestra habitación. ${ }^{3}$

El ensayo crea así un pasaje imaginario. Los padres que no pueden salir de las fronteras soviéticas ven América a través de la escritura del hijo. Brodsky, que no puede desandar el camino para reingresar a su patria, ve a través de la escritura su casa en Rusia y en esa casa se ve a sí mismo, a ese que él era antes de que todo se desmoronara por el exilio.

Si el exilio es sinónimo de fragilidad y desamparo, no es extraño que de todos los escenarios posibles que Brodsky podía haber elegido para narrar su memoria familiar, haya optado por el recuerdo de esa habitación pequeña donde transcurrió parte de su vida y que ahora, desde Canadá, evoca con un tono vacilante que no deja nunca de estar punteado, a pesar de que él lo niegue, por la nostalgia.

No hay literatura del exilio que no erija a la propia casa como meta del recuerdo, como metáfora del despojo o como sitio emblemático que resguarda, más allá de las distancias, algo de eso que en la lejanía se sigue siendo. Pareciera que en la memoria de aquellas casas natales arrasadas por la fuerza o

${ }^{3}$ Brodsky 1995, 180. 
el designio de la historia perdurara, como en ningún otro espacio, una pureza imposible de ser avasallada por ninguna maquinaria destructiva, por ningún viento brutal de la historia.

Aún las moradas más frágiles resisten a las tempestades más férreas. Y las que fueron devoradas por la aniquilación, pueden rearmarse, como la de Brodsky, en la amalgama sutil del lenguaje labrado en la otra lengua, la del exilio.

Las casas de la infancia insisten con dolor en el alma y la memoria de los huidos. Y a veces su recuerdo es lo más parecido a un bálsamo que cura o calma el sufrimiento de padecer injustamente la intemperie. No importa bajo qué régimen, bajo qué dictadura.

En su novela Las cartas que no llegaron el uruguayo Mauricio Rosencof rearma desde el cautiverio las formas que tuvo alguna vez la casa pura de la niñez. Quien narra está encerrado en un pozo, negado de toda relación con la luz y las palabras, y, sin embargo, desde esa oscuridad logra regresar a través del tiempo a esas escenas en las que la juventud era sinónimo de inocencia. La casa que reconstruye Rosencof en su memoria es la de sus padres, inmigrantes polacos huidos de la devastación de la guerra europea. Una casa montevideana construida para conjurar la que les fue arrebatada por la Gran Hecatombe. Una casa elevada desde las ruinas de su memoria familiar y que ahora, en el presente en el que Rosencof la recuerda, se une a esa otra devastación, la que produjo la última dictadura uruguaya de la década de 1970.

Más allá de los contrapuntos que Rosencof logra establecer entre la memoria europea y la memoria americana, entre la historia de la destrucción europea y su inscripción en la memoria familiar rioplatense, es interesante destacar esa reconstrucción paciente del patio y las habitaciones familiares a la que la novela retorna una y otra vez. El relato rearma diálogos perdidos, escenas familiares, va en busca de las miradas jóvenes que alguna vez tuvieron los progenitores describiendo con 
melancólica delicadeza los modos en que la guerra europea golpeaba en el interior de esa casa montevideana, de qué modo esa casa era un eco de aquellos episodios que la historia estaba escribiendo de manera trágica en la otra orilla del mundo, como si ese espacio fuera un mágico aleph en el que se condensaran el vértigo, la incertidumbre y la esperanza de aquellos años.

La primera mitad de la novela de Rosencof reconstruye la imagen antigua de los padres libres; la segunda los ve, al igual que Brodsky, ya mayores y cansados. El hijo vuelve para verlos pero ellos a duras penas lo reconocen. La casa de la infancia ha sido abolida y el único lugar cierto donde poder reencontrarlos es entonces el que diseña imaginariamente, con sus ensoñaciones, la literatura.

Dice Bachelard:

[...] la casa no se vive solamente al día, al hilo de una historia [...] Por los sueños las diversas moradas de nuestra vida se compenetran y guardan los tesoros de los días antiguos. Cuando vuelven, en la nueva casa, los recuerdos de las antiguas moradas, vamos al país de la Infancia Inmóvil. Nos reconfortamos reviviendo recuerdos de protección. Algo cerrado debe guardar a los recuerdos dejándoles sus valores de imágenes. ${ }^{4}$

El narrador de Las cartas que no llegaron va entonces del encierro frío de la prisión hacia ese refugio primero e insustituible que es la casa paterna para revivir una protección que sólo puede brindar el abierto amor de los padres.

En un diccionario de ideas afines el concepto de puerta está asociado al de casa. Pero no. Yo duermo de cara a una puerta que es hermética, consistente, gorda, donde a veces llego con mis nudillos tímidos para ir al baño [...], con un agujero no

${ }^{4}$ Bachelard 1965, 189. 
más grande que una moneda, por donde me tienen bajo la vista, y les veo el ojo que sonríe o vigila o vigila sonriente; mi puerta, hoy, es eso. No da a ninguna casa $\left[\ldots . .{ }^{5}\right.$

Que una puerta dé a una casa, que se abra a un espacio que sea familiar, propio y no extraño es, tanto en los cautivos como en los exiliados, un deseo tan poderoso como las cadenas que los tienen atados al afuera de la patria; de allí que en las memorias, en los textos escritos por exiliados, siempre la casa paterna adquiera esa dimensión superior e inalcanzable del deseo, poderoso anhelo que los poetas hebraico-españoles supieron atrapar con sutileza cuando escribían sus siónidas y $\mathrm{ki}$ not. Las primeras para narrar y describir la dolorosa cautividad a la que había sido sometida la Casa primera (representada por la imagen del Templo destruido en manos de los extranjeros, los edomitas); las segundas, las kinot, para nombrar la destrucción de las casas del exilio y el despojo al que éstas habían sido sometidas.

No me quejé de que me robaran mi fortuna; no me importó que se desvaneciera y evaporara. No me lamenté de que se acabara la opulencia, ni me sentí enfermo cuando mis servidores desertaron [...]. Pero sin embargo las lágrimas fluyen de mis ojos y el dolor me vence por haber quedado solo en la tierra natal, sin un amigo a mi lado. Me siento como extranjero y advenedizo; no veo a mi alrededor a nadie de mi familia, a nadie de la casa de mi padre.

Sigo en Granada como un extranjero, soy en esta ciudad, cuyo bullicio y esplendor han declinado, como un gorrión que ha perdido su nido. Soy como un pájaro desterrado, no hay refugio para mí y no queda nadie que se acuerde de mi persona y se interese por mi salud. ${ }^{6}$

\footnotetext{
${ }^{5}$ Rosencof 2000.

${ }^{6}$ Ibn Ezra 1977.
} 
El texto pertenece a Moshé Ibn Ezra y si bien no narra el exilio propio — de hecho fue escrito en Granada-, describe la soledad por el dolor de aquellos que se han ido y la extrañeza que esa partida le confiere al lugar natal. "No veo a mi alrededor a nadie de mi familia, a nadie de la casa de mi padre". El exilio ha transformado a los ojos de Ibn Ezra la casa natal en una ruina que sólo podrá ser recuperada, lo sabemos, cuando los otros poetas, ya desde el exilio, rearmen la casa española y le confieran los atributos de un paraíso perdido.

Cautivo como Ibn Ezra, Mauricio Rosencof en medio de las ruinas en que la dictadura uruguaya ha convertido su propio territorio, vuelve, luego de la liberación, a buscar los patios de la infancia. La madre y el padre antes jóvenes son, por fuerza biológica, ancianos. La casa ha sido confiscada por el Estado y los que elevaron sus cimientos han sido recluidos en un patio de un asilo de ancianos. La escena que narra ese reencuentro no puede dejar de insistir en la memoria en contrapunto con aquellas otras en las que los padres son vistos como los hacedores de un mundo en el que todo estaba signado por la idea de posibilidad. Sin casa paterna a la que reingresar, todo parece vacilar bajo los pies de aquel que vuelve del cautiverio o retorna del exilio. Por eso, el narrador de Las cartas se asemeja tanto a un desterrado en busca de las imágenes últimas que avizoró antes de la partida. La ancianidad de los padres resume en esa escena más que el paso feliz y lógico de los años, la negación de la posibilidad de un tiempo compartido entre el hijo que vuelve y el padre que ha esperado, una metáfora de la violencia de ese cisma provocado por la adversidad de la historia y que ha separado al hijo de su casa materna, y antes, muchos años antes, al padre y a la madre de su aldea polaca.

En su preciso ensayo dedicado a las diferentes formas de habitar, Gaston Bachelard nos enseña que toda casa de la infancia puede ser resumen del Universo y que su recuerdo, cuando estamos lejos de ella, puede convertirse en conjuro de 
la melancolía o refugio imaginario para nuestra soledad. Cuando las casas de la infancia ya han desaparecido, no nos queda más recurso que recrearlas con la memoria y si es el exilio o el destierro el que se las ha llevado de nuestro lado no hay más alternativa que reinventarlas. Buena parte de la poesía del cubano José Kozer, quien abandonó la isla junto a toda su familia en el año 1960, puede ser incluida dentro de esa categoría de textos obsesionados por reconstruir las formas que tuvo alguna vez esa casa-morada abandonada como consecuencia del exilio. Hay un poema que bien condensa esa sensación, no la de la dulce recreación del pasado como Paraíso perdido, sino la de un ayer en el que la casa comenzó a dejar de ser aquello que él hubiera deseado que fuera.

\section{DIÁSPORA}

La tienda de La Habana está en el polvo,

En el polvo está el dril importando de Irlanda,

Y mi padre, judío polvoriento,

Regresa día a día con el pan de centeno en el brazo.

Regresa día a día, siempre idéntico,

Ojos oblicuos de casimir rayado,

No parece un capitán sacudiendo las retinas,

Regresa a casa, parece un cráter áspero y alegre.

Viene papá y almorzamos mirando las molduras del techo,

Jamás vi entrar el agua, no veo un pez ni una maceta,

Mi madre vuelve a pulir la talla de los muebles, cambia las sábanas del jueves,

No hemos visto una flor en todos los dormitorios de la casa.

Todas las tiendas de La Habana se han cerrado,

Los obreros se han puesto a desfilar enardecidos,

Y mi padre, judío polvoriento,

Carga de nuevo las arcas de la Ley cuando sale de Cuba.

El poema describe las formas de una casa hechizada en la detención. La Revolución ha arrasado como una furiosa tempestad 
todos los rincones del hogar paterno y ha logrado modificar a los integrantes del clan familiar, los ha llenado de polvo como ha empolvado las tiendas de La Habana y el silencio en torno a la mesa cotidiana hace un contrapunto con la bulliciosa algarabía que los enardecidos obreros despliegan sobre las calles de la ciudad alzada, como si la casa paterna fuera un bastión inexpugnable, un sitio fuera de la Historia o desde el que se resiste a esa nueva forma que ha asumido la Historia.

La imagen del padre cargando nuevamente las arcas de la Ley para retornar al exilio o ampliar el exilio milenario del que ya viene arrastrando el linaje dice, a su modo, de lo fugaz y transitoria que toda casa es para un pueblo de errantes. Como aquellos acólitos de Maimónides que hacia el siglo XII abandonaron sus casas españolas porque según las consejas del maestro no se debía vivir sobre el mismo suelo que habitaba el tirano, la poesía del hijo descubre al padre buscando la libertad fuera de la tierra que ahora la Revolución ha decidido identificar como Prometida.

"La poesía de Kozer — señala Jacobo Sefamí- puede partir de un vacío, una ausencia, pero para aglomerar imágenes y ofrecer un lleno". ${ }^{7}$ Siguiendo esta idea, la pérdida producida por el exilio puede ser vista entonces como una puerta abierta al umbral de un espacio que necesita ser llenado constantemente. O, de otro modo, las casas que habitan la memoria de Kozer son casas que, al haber sido despojadas de sus originales moradores, se convierten en espacios continuamente ocupados por imágenes nuevas. Como si el vacío fuera un fabuloso prodigador de sentidos y sensaciones nuevas. Imán en el que confluyen voces, cuerpos, sensaciones, aromas reales e imaginados. Así, la lejana y ya inexistente morada habanera se sigue construyendo en el poema, a pesar de ser un territorio desvanecido en el tiempo. ${ }^{8}$

${ }^{7}$ Sefamí 2000.

${ }^{8}$ En este sentido, podría decirse que Kozer brinda a sus antiguas moradas el mismo tratamiento que los judíos prodigaron a Jerusalén una vez producido el primer 
En otro de sus poemas titulado "Retrato sideral de mi casa" la escritura de Kozer vuelve como en "Diáspora", a una Habana antigua y perdida en los laberintos de la memoria. La mirada del poeta sobrevuela azoteas, penetra en la noche oscura e insular para anunciarle a los muertos que aún sobreviven deambulando en el éter, que el que se ha marchado está nuevamente allí, que ha regresado para lamer las manos sudadas de miel y ámbar de sus antepasados. ${ }^{9}$ Un gesto que se repite en "Te acuerdas Sylvia" cuando al final del poema dedicado a rememorar una escena familiar dice:

Recuerdas Sylvia cómo trabajaban las mujeres de la casa.

Parecía que papá no hacía nada

$[\ldots]$

Recuerdas Sylvia, cuando papá llegaba de los almacenes de la calle Muralla

Y todas las mujeres de la casa se alborotaban.

Juro que entraba por la puerta de la sala, zapatos de dos tonos, el traje azul a

rayas, la corbata de óvalos finita

Y parecía que papá no hacía nunca nada.

El diálogo imaginario con la hermana permite rearmar la casa de la infancia arrasada por el paso del tiempo. Son imágenes del padre que polemizan por su verosimilitud con la memoria de cada uno de los miembros de la familia y que el poema pone en evidencia a través de una aseveración indubitable cuando dice "juro" como imponiendo esa imagen, la del

exilio. Como consecuencia de la destrucción del Templo el vaciamiento de ese útero sensible a la comunidad fue constantemente llenado con imágenes. La poesía del exilio y las plegarias elevadas con unción cada mañana no hacen más que enfatizar el deseo de cubrir con palabras la dimensión de ese vacío traumático. Cuanto más inmenso ese vacío sentido por el lugar amado-arrasado, más palabras son dichas para cubrir la extensión de lo perdido.

${ }^{9}$ Véase Kozer 1988. 
padre entrando por la puerta de la sala y por ninguna otra puerta, ese gesto por sobre todos los gestos posibles.

El poema de Kozer pone en movimiento la casa detenida en el pasado, y por un instante, como sucede con la magia de los recuerdos, la casa del ayer vuelve para que el poeta la habite en el presente. Un intento, como diría el mismo Kozer, de anular ese vacío cósmico producido por el exilio, una forma de restituir mediante el lenguaje la abolición del derecho a habitar un espacio geográfico propio, un sitio particular en el mundo, no otro que el de la propia casa paterna que alguna vez tuvo la forma del Universo. ${ }^{10}$

Dice George Eliot:

No hay tranquilidad como la que sentimos en los escenarios donde hemos nacido, donde empezamos a querer los objetos antes de conocer el trabajo de elección, y donde el mundo exterior parecía sólo una extensión de nuestra personalidad. ${ }^{11}$

Y es que toda distancia del hogar natural cuando es impuesta por la fuerza o la violencia no puede ser más que traducida bajo la forma o la imagen de la intranquilidad. En el afuera de la casa natal, toda lejanía se convierte en intemperie, toda distancia en abismo, todo acontecimiento en extrañeza.

Así, el exilio es la vida vivida fuera del orden habitual, discontinuidad pura del ser. ¿Qué hay que sea más habitual que la vida que llevamos dentro del hogar, emparentados con los aromas, con los ruidos secretos, con los cambios de luces según pasen las estaciones?, ¿en qué lugar del mundo cumplimos con más exactitud que en nuestras casas eso que llamamos rituales cotidianos y que cuando nos faltan, por razón de la violencia, el mundo parece vacilar o quebrarse?

\footnotetext{
${ }^{10}$ Véase Kozer 2000.

${ }^{11}$ Citado por Said 1984.
} 
¿Quién puede abolir la profundidad de ese cisma, quién puede volver a hacer que todo sea, aunque sólo acontezca en el terreno imaginario de la página, habitual, sino la literatura?

En la atmósfera invernal en la que Brodsky escribe y reconstruye desde el exilio las formas de su casa paterna atrapada por las fronteras burocráticas soviéticas, en el implacable interregno que durante cinco años oscureció el cielo del Río de la Plata y en cuyo corazón Rosencof escribe esa inmensa memoria del hogar de la infancia con todas sus voces y todos sus aromas, en los poemas de Kozer cuyas palabras miman desde la distancia los fantasmas que sobrevuelan las casas habaneras abandonadas a causa de la huida, un mismo anhelo reconstructivo puede ser reconocido. Cada uno de esos textos dice y ratifica de manera elocuente la intangible y a la vez poderosa capacidad que posee la escritura como instrumento esencial, casi único, a la hora de reconstruir los paisajes y lugares propios que fueron devastados por la fuerza implacable de los más fuertes.

Contra los discursos altisonantes, preclaros, nada ambiguos, enunciados a través de los lenguajes oficiales el vacilante discurso literario caracterizado por lo incierto, lo dudoso, lo improbable, emblematiza a su modo una de las formas de la resistencia al hacer presente lo que ya no está, lo que abolido parecía desaparecido para siempre.

Así, es la literatura la que vuelve, luego del paso del pogrom, de la patota, de la policía secreta, luego del asalto del ejército por sobre los muros de las moradas familiares para reconstruir aquellas casas y testificar sobre sus antiguas ruinas las consecuencias que ha dejado ese paso violento. Acaso resida en esa cualidad reconstructiva su valor más poderosamente mágico e inquietante: fija en la letra y salva de la evaporación aquello que a la memoria irremediablemente se le desvanece.

Allí donde hay casas que se derrumban, allí donde hay patios vacíos barridos por el viento y allí donde parece que sólo 
la calamidad del desierto es lo probable, la literatura retorna con la fuerza inextinguible de la evocación, para hacer de esas ruinas, de esas tierras baldías, de esos solares inhóspitos, el más cálido de los refugios, nuevamente.

Vuelve para poner ladrillo sobre ladrillo, para elevar los umbrales caídos y, como en los poemas de José Kozer, para darle voz a los que, ya muertos, deambulan solitarios y desconsolados en el invisible éter del Universo.

\section{REFERENCIAS}

Bachelard, Gaston, 1965. La poética del espacio, Buenos Aires, Fondo de Cultura Económica.

Brodsky, Joseph, 1995. "En una habitación y media", en Menos que uno, Barcelona, Altaza.

Ibn Ezra, Moshé, 1977. Epistolario, Buenos Aires, Losada.

Kozer, José, 1988. "Retrato sideral de mi casa", en Carece de causa, Buenos Aires, Último Reino.

—, 2000. "El último de los mohicanos: un cubano judío", Revista Iberoamericana, 191, Pittsburgh, abril-junio.

Rosencof, Mauricio, 2000. Las cartas que no llegaron, Buenos Aires, Alfaguara.

SAID, Edward, 1984. "Recuerdo del invierno", Punto de Vista, Buenos Aires, VII, 22.

SEFAmí, Jacobo, 2000, "Llenar la máscara con la ropa del lenguaje", Revista Iberoamericana, 191, Pittsburgh, abril-junio. 